\title{
Deterioration of World Heritage Cave Monument of Ajanta, India: Insights to Important Biological Agents and Environment Friendly Solutions
}

\author{
Sunidhi Singh ${ }^{\circledR}$, Shalini Dhyani *, Piyush Kokate ${ }^{\circledR}$, Soumya Chakraborty and Sagar Nimsadkar \\ National Environmental Engineering Research Institute (CSIR-NEERI), Nehru Marg, Nagpur 440020, India \\ * Correspondence: s_dhyani@neeri.res.in
}

Received: 1 July 2019; Accepted: 20 August 2019; Published: 30 August 2019

\begin{abstract}
Heritage monuments across the world are affected by a variety of physical and biological stresses. Damage to heritage monuments due to insects and pests is growing with increasing anthropogenic pressure and changing climatic conditions. Cave monuments are habitats to microbes, algae, fungi, and insects, and are unique biodiversity sites due to their low temperature, little to no sunlight, and high moisture conditions. This study takes stock of available information on important factors that facilitate the growth of insect pests and degrade heritage monuments. Ajanta Caves, a UNESCO world heritage site in India, is a human marvel, important archaeological and heritage site of immense cultural and historic values. The present paper is an attempt to understand a variety of stresses and factors with a focus on insect pests that have substantially affected Ajanta cave paintings in the last few decades. The study also provides information on available approaches for damage control including the need for an integrated insect pest management for protecting cave monuments against rapid degradation across the country in general and Ajanta caves in particular. A light-based approach is the key highlight of the study that can be used as an effective and efficient approach to protect archaeological sites especially cave paintings from insect pests without disturbing the pollinator diversity and surrounding environment.
\end{abstract}

Keywords: heritage monuments; Ajanta caves; light-based control; heritage; pollinators; pest control

\section{Introduction}

Heritages structures are considered to be of immense value to society, culture, and country as they reflect the history and uniqueness of the place [1]. Historical monuments can be made of materials such as rocks, stones, plaster, paper, wood, and painting materials [2]. In the last few decades, heritage sites and structures across the world are observed to have undergone huge degradation [3]. Degradation of monuments may be due to microclimate (temperature, humidity, darkness) and/or biological agents (microorganisms, plants, algae, fungi, birds, bats, and insects) [4]. India being rich in cultural and historical heritage has many historical buildings and heritage monuments, mostly administrated and conserved by the Archaeological Survey of India (ASI) [5]. Many of these ancient heritage monuments are located far from human habitations inside forests, pristine areas including in secluded caves. Ajanta, Ellora, Elephanta, Guntupalle, Bhaja, Karla, Bedse, Kanheri, Saptaparni, Udayagiri, and Khandagiri are some of the famous cave monuments of India. Heritage monument of Ajanta is a series of rock-cut Buddhist caves are human marvels and they showcase the excellence of artistic and technical achievement [6]. Buddhist monks constructed Ajanta caves long back in the Vakatakas period [4]. These caves are renowned for the wall paintings of Hinayana and Mahayana beliefs of Buddhism [7]. Before 1819, the caves were lost in anonymity and it was only in the year 1819 when the caves were rediscovered by the Officer of British Battalion Mr. John Smith [4]. Since 1983 
Ajanta caves have been declared UNESCO world heritage site [2]. In 1995, the Government of India declared Ajanta caves the monument of national and heritage value [7]. In 1953, the Archaeological Survey of India undertook protection and preservation of Ajanta caves, rock carvings as well as paintings [5]. In general, caves across the world have been one of the most obvious and fascinating habitats for the presence of unique biodiversity especially insects [7]. Insects along with bats survive in dark cave habitats having unique environmental conditions (darkness, dampness, etc.) [4]. Insect species inhabiting caves may be complete or partial cave dwellers [2]. Insects are reported to be frequent visitors in the Ajanta caves due to the location of the monuments in the densely forested area, with high humidity, low temperature in the caves in comparison to outside dry weather and almost negligible sunlight penetrating the caves [4]. Warmer climate and humidity increase the number of insect pests close to historical properties [8]. Future and ongoing changes in climate variability and rainfall patterns are observed to increase presence and degradation of monuments due to the rise in insect and pest populations [8]. Research on protecting heritage monuments against biological agents especially insect pests and factors that accelerate the insect pest population has been underexplored and mostly understudied. The present study is an effort that provides information on various physical and biological stresses to the cave monuments. The focus of the research paper is on pertinent conditions and factors that have affected the world heritage structure and are attract an array of insect pests that have affected and substantially degraded the cave monument and paintings. To develop effective and efficient solutions for insect pest management and protecting the heritage structures/monuments there is a need for interdisciplinary efforts. Interdisciplinary approaches across subject boundaries with innovative ideas and interface between subjects have the potential to provide novel research ideas and effective solution to tackle the concerns. Considering the background of the heritage importance of the Ajanta caves in India and ongoing damage to the structure due to a variety of factors that have affected the heritage structure study provides an overview of factors that have substantially affected the structure and paintings with a special focus on insect pests. This paper tries to highlight the phototactic behavior of insect pests that can help as important control without using chemicals that can harm the cave monument as well as surrounding pristine environment and pollinator diversity. The study endorses the importance of the light-based system for cost-effective and environmentally sustainable insect pest management for heritage monuments. Though a study is localized in Ajanta similar instances and examples have also been learned from different ancient cave monuments and heritage sites of the country. These lessons emerging from the study will be valuable for understanding and implementing the light-based solutions to the cave monuments and sites where site-specific issues and problems related to insect pests persist.

\section{Study Area}

The Ajanta caves, a world-famous UNESCO heritage site, is located at latitude $20^{\circ} 33^{\prime} 12^{\prime \prime} \mathrm{N}$ to $75^{\circ} 42^{\prime} 01^{\prime \prime}$ E longitude, at $33.5 \mathrm{~m}$ AMSL in Aurangabad district of Maharashtra, India (Figure 1). The Ajanta caves are great volcanic formations of the basalt plateau of Deccan trap and among the largest national and world heritage sites [4]. The cave monument of Ajanta is 30 caves of decorated mural paintings representing the past lives and rebirths of the Buddha, pictorial tales and rock-cut sculptures of Buddhist deities carved in the 2nd century B.C., along Waghora River with horseshoe-shaped cliff caves [3]. Twenty-five caves out of 30 caves are monasteries (Viharas) and the rest are temples (Chaityas) [8]. The highest temperature has been observed in April with a monthly average temperature of $32{ }^{\circ} \mathrm{C}$ with lowest from January. In the rainy season, the daily average humidity was $80 \%$ and $40 \%$ during the dry season. According, to Tomoko Uno and Yoshiko Shimazdu [9] from July to September the monthly rainfall has been reported to be over $150 \mathrm{~mm} / \mathrm{month}$. Ajanta caves are surrounded by tropical dry deciduous forest that includes drought-tolerant trees like Anjan (Hardwickia binata), Khair (Senegalia catechu), Dhawada (Anogeissus latifolia) (www.himalayandays.blogspot.com). Valleys in the study area have got diversified vegetation covered with Euphorbia species and along with the river moist zone species of Terminalia arjuna and Santalum album [10]. 


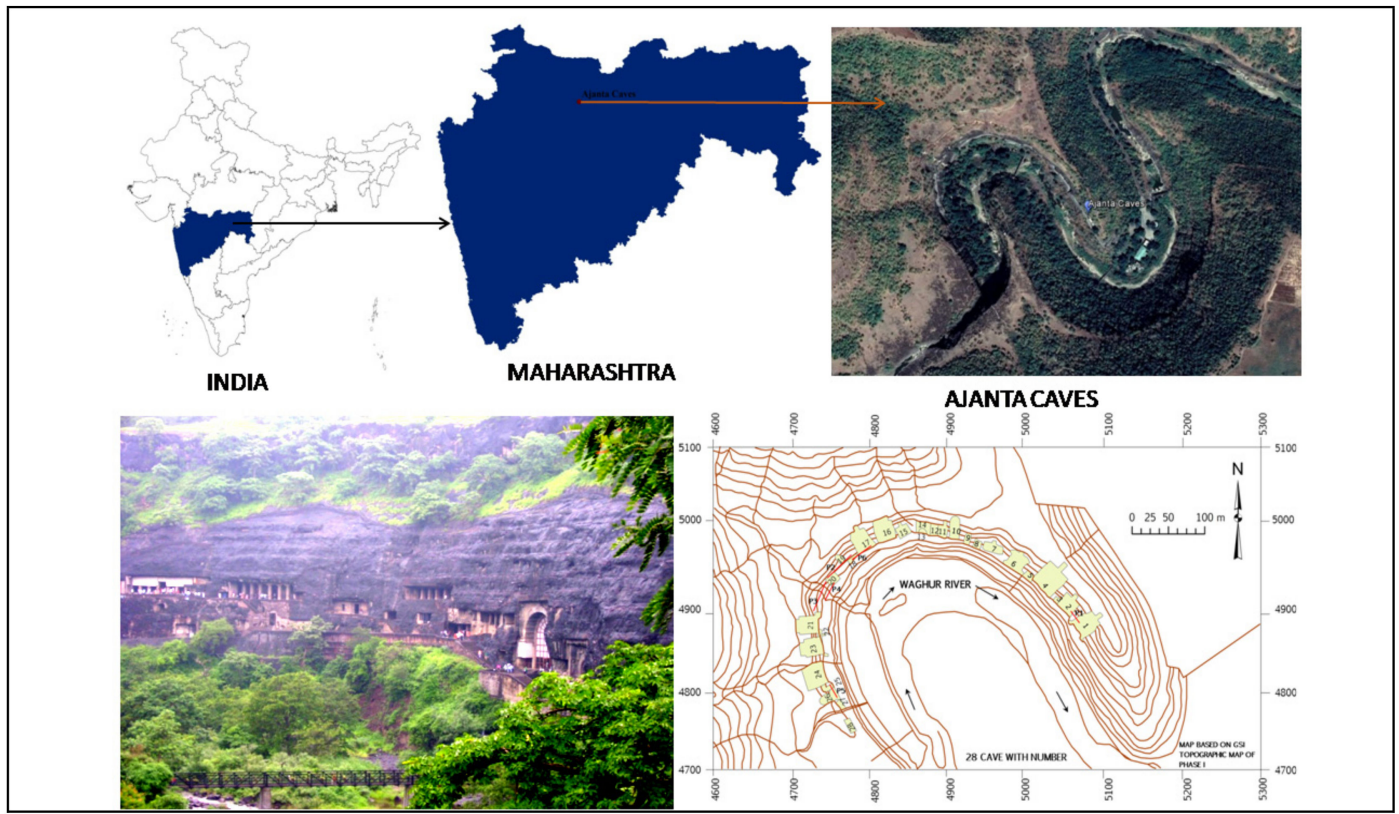

Figure 1. Ajanta Caves (top left), Satellite image of the study area (top right), picture of scenery from the study area (bottom left), topographical map of the study area (bottom right).

\section{Methodology}

Considering the background of the study that provides an overview of important factors that have facilitated the population of insects in Ajanta caves and have affected the heritage paintings systematic research review was carried out to understand the key factors that have resulted in the proliferation of insects and deterioration of Ajanta caves and paintings. Systematic research review helped in understanding the root cause for damage to caves and especially paintings. Concepts present in the paper are based on evidence on the deterioration of heritage structure due to a variety of stresses that were received from the review of the literature. Detailed information about heritage paintings and caves of Ajanta and different factors affecting and leading to the deterioration of monument also was taken into account by focused group discussions and personal interviews with the officials of Archeological Survey of India (ASI) and State forest department stationed in the office of Ajanta, Aurangabad Circle, Maharashtra India. The focus of these personal discussions was prominent factors that have caused large damage to caves especially biological agents; chemicals and other options being used to reduce the damage to paintings and insect pests. Grey literature available on the management of insect pests in heritage monuments was also reviewed to develop a better understanding of the issue. The linkages of different physical and chemical factors for the presence of insects was also assessed through field surveys and talking to field staff following formal and informal group discussions and data verification by actual field checks.

\section{Results and Discussion}

Ajanta caves are situated in a forested natural landscape with the significant presence of varied biodiversity elements [10]. Though not many insect pests have been reported from Ajanta caves and the reason has been no work been carried out in this direction by Zoological Survey of India (ZSI) or any other Government agency in the region [11]. The most common insects reported from the area in literature were silverfish (Lepisma saccharina) [2], Coleoptera, and bugs [12]. It was reported that muddy water entered the caves of Ajanta after the priests surrendered the spot thousands of years ago [7]. Rainwater and water from Waghura River constantly entered the caves taking mud leading to dampness in the cave atmosphere and increase in algae, fungi, and variety of insects and microbes [8]. 
Methodical harm to practically all the stone cut pillars of the caves was due to the influx of water in the caves. One quarter of Ajanta paintings are reported to be lost due to damage caused by algae, fungi, insects, and pests [8]. Many anthropogenic activities have attracted biological agents like algae, fungi, microbes, and insects resulting in degradation of the cave paintings as well as statues and stone carvings [9]. Penetration of woody roots of vegetation on cave roofs have resulted in crack formations, penetration of stream and rainwater giving entry to microbes, algae, fungi, and insects [12]. A mixture of hemp, clay, and lime plaster was considered efficient for preserving paintings and carvings in nearby Ellora caves [13]. Lime plaster and hemp is reported to regulate humidity and control insects in Ellora whereas, hemp has been not used in Ajanta caves and has likely resulted in deterioration of painting and cave walls to algae, fungi and insect presence [9]. Algae, fungi, and microbes provide enough food to insects for their survival inside damp cave monuments [6].

\subsection{Deterioration of Ajanta Caves}

Fruit bats and bird (pigeons) were visiting Ajanta caves when sufficient protection was not provided to the heritage site and it was open unhindered throughout the day [8]. Bat and bird excreta are rich in organic nutrients that serve as a food source for microorganism, algal, fungal, and insect proliferation [2]. Though, in the last few years, the Archaeological Survey of India (ASI) had protected the caves from birds and bats by fixing doors on cave entry (whc.unesco.org). Previously, Ajanta cave paintings were studied, coating the paintings with varnish without removing the dirt and soot [3]. This was done for clarity and to understand the minute details and to fix the flaking paint. But consequently, the original color was changed considerably from white to yellow, blue to green, and so on [3]. It was also noticed that in some caves at Ajanta, there was a layer of white, brown, or black substance over the paintings [14,15]. The basal layer of the Ajanta murals and paintings on the ceiling are composed of mud plaster and organic matter locally available paddy husks, vegetable fibers, grass and fibrous material overlaid with lime, kaolin, or gypsum [2]. The base of the paintings i.e., vegetable husks, organic materials mixed with the plaster is a good breeding place for microbes, fungi, and insects [4]. Microbes feed on binding materials that are important food and result in deterioration of heritage paintings [6]. Micro-organisms like fungi attack these binding materials of the painting and can penetrate deep into the substratum and destroy the structure, and even produce fissuring of the paint layer, peeling, friability, and collapse due to the effects of the enzymes they secrete [16]. According to the mineral structure of the stone, it was found that in some of the caves blue-green powder was formed [2]. Algae and fungus are prominent on damp and moist places that are important feed and food to many small insects and larvae [17]. The walls of Ajanta caves at many places can be seen dark and covered with the fungus that facilitates breeding of small insects [18]. One can see black walls because of the seepage of water in cave walls [10]. Growth of fungus on the plaster is common, because it can survive on a very small amount of organic substance contaminating the surface of the substratum [2]. Some crystals have been completely converted into powder and have resulted in the formation of holes [16]. These holes have served as a surface liable for deposition of dust, dirt, fungus, algae, and hiding places for insects [2]. Paintings in Ajanta have been covered with dust, fungal, or algal coatings and are excellent habitats to insects and their nests because of the varnish coating that was used to preserve the paintings during early times [4]. Insects lay egg in the flaking and peeling of the painted surface of the caves [5]. The presence of organic matter admixed with the mud plaster is an excellent breeding place for microbes, fungi, algae, and insects whereas, insect created holes are evidence of damage caused [4]. Most of the damage to the Ajanta paintings have been observed due to silverfish (Lepisma saccharina) and few unidentified Coleoptera species that are a common presence in damp and moist book libraries [13]. Coleoptera mostly feeds on dried leaves, litter, and cow dung (organic matter) [2]. Silverfish (Lepisma saccharina) live to an expansive degree on carbohydrates and most likely feeds on certain condensed cellulose (again organic matter) and it can also flourish with little measures of proteins and gum or paste utilized in wall paintings [19]. Silverfish (Lepisma saccharina) were mostly observed on the back of the paintings in Ajanta Caves where they get to feed on the loose 
plaster and use this space as their habitat [13]. Insects like Blattaria larvae and pupae of Lepidoptera mostly unidentified till date were also observed from Ajanta caves adapted to the dark and damp atmosphere [16]. A general food chain of Ajanta cave monument is presented (Figure 2). The humidity inside Ajanta caves is mostly $55 \%-60 \%$ whereas temperature is $25^{\circ} \mathrm{C}$ [19]. The temperature in the caves stays static from $27-30{ }^{\circ} \mathrm{C}$, but there are large fluctuations in humidity from around $80 \%$ during monsoons (July-September) to 40\% during late springs (March-April) [20]. This has resulted in flaking of colors, the formation of cracks, edges, holes on the painted mortar [21]. Tomoko Uno and Yoshiko Shimazdu [10] have reported a special influence of temperature and humidity inside the caves as one of the major causes of degradation heritage paintings. The dry and wet cycles of humidity are reported to have caused the expansion and contraction of the plaster which has detached the plaster from the cave walls [22], whereas in low humidity conditions, the paintings get detached from the walls as the paint binder becomes friable [10]. Temperature and humidity are also potential drivers to facilitate algal, fungal, and insect larvae, pupae, and adults to use the caves for their habitat, as well as for breeding place [23]. Dampness is one of the reasons for decay of the wall paintings of Ajanta, as it encourages the breeding of microbes, insects, and pests [24]. Deterioration of the mural paintings gets accelerated as the humidity changes due to the presence of bats and bat excreta on the ceiling, sidewalls, and also over the paintings which have high moisture absorbency as it undergoes repeated contraction and expansion [3]. Even after the obliteration of the bats and birds by ASI initiatives from the caves, the deterioration of the painting continues in the caves where the bat and bird excreta has penetrated in the mud mortar and stone surface [2]. Bat and bird excreta under the persistent damp conditions of the caves has percolated over broad zones of the artistic creation and has substantially damaged the paintings. The moderate deterioration of urea, an essential constituent of bat's excreta makes perfect conditions for frightening insect activity [18].

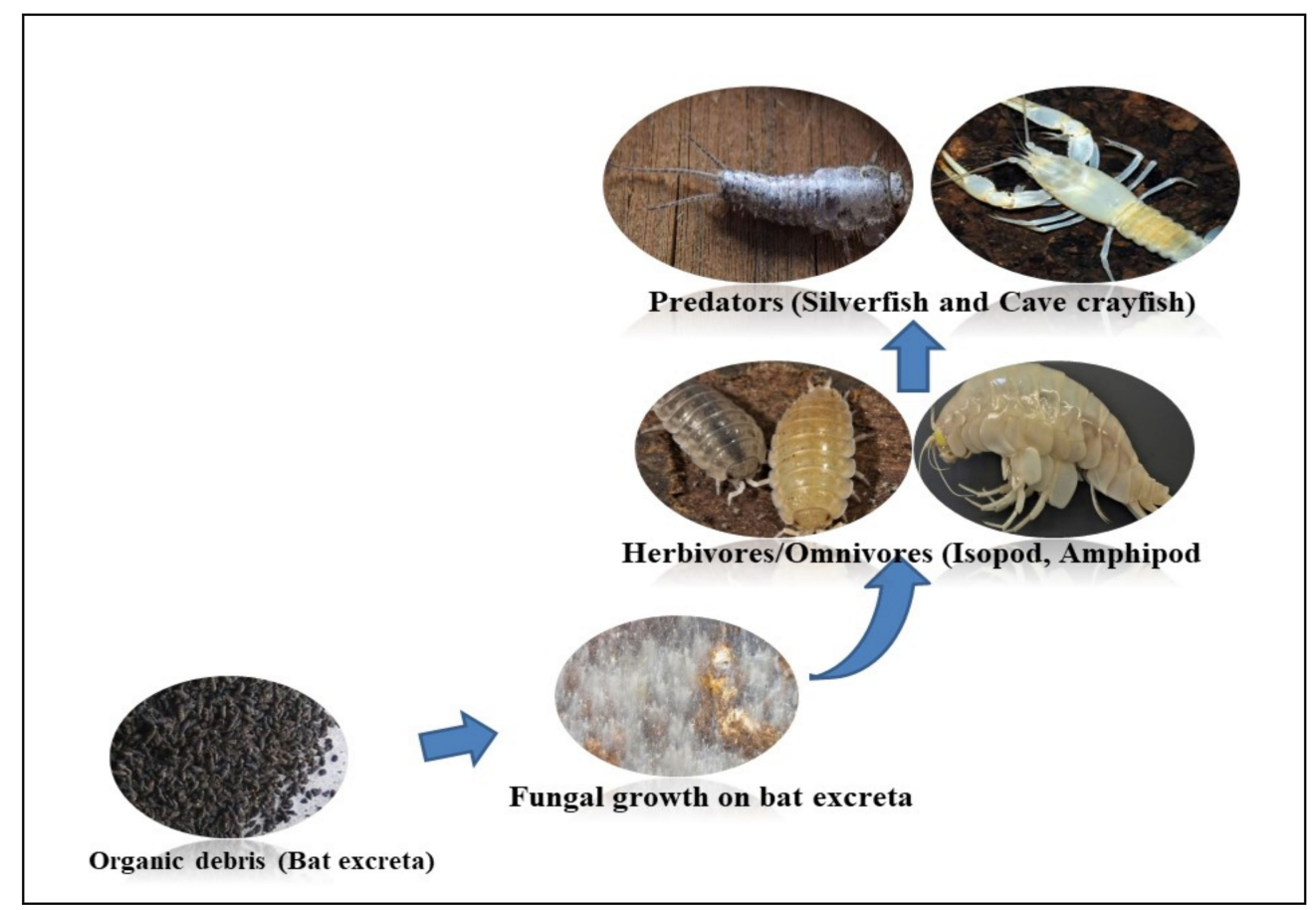

Figure 2. A hypothetical food chain for the cave monument of the Ajanta Caves. 


\subsection{Insect Behavior for Damage Control}

Most insects do not have specialized detectors for airborne or natural noise including ultrasound [16]. Few insects can be located based on the noise they make. The Gryllus species produces an acoustic signal with carrier frequency between $3-6 \mathrm{kHz}$ that attracts nonspecific females [16]. It is evident that certain insects make a certain sound to attract opposite sexes for breeding and may later use the place as a potential habitat resulting in degradation of the substrate and habitat due to their mass presence [16]. The presence of Gryllidae and associated insects cannot be avoided in the said situation of Ajanta caves due to sufficient dryness, dampness, and presence of water [5]. Light behavior of insects is important to be understood as insects can respond to diverse wavelengths of light as per their light behavior [22,23]. Many nocturnal and few diurnal insect species are positively phototropic (phototactic) and are attracted towards the source of light [24]. They get attracted to light in a variety of ways and phototaxis is one of the major responses to light. Different phototactic behaviors exhibited by insects are as follows [23]:

(a) Attraction: Also known as positive phototaxis. Many insects usually follow this light behavior and get attracted to the light source e.g., Lasioderma serricorne, and Trogoderma granarium. One can observe this common light behavior of insects during showers when a lot of insects get attracted to light source [3].

(b) Repulsion: Also known as negative phototaxis. In negative phototaxis, insects move away from the light source e.g., Tetranychus urticae, and Neoseiulus womersley. Negative phototaxis is a little rare in comparison to positive phototaxis behavior of insects [8].

Insects use and respond to light for various activities like biological rhythm (partitioning between day and light), dark repair and recovery, circadian clocks and photoperiodism, visual perception, and spatial orientation [22]. Nocturnal insects get attracted towards the light sources that emanate UV (Ultraviolet) radiation such as light traps, and street lamps [23]. Many diurnal species also get attracted towards the yellow light traps such as yellow pan traps, yellow sticky plates and yellow lamps [25]. Yellow lamps have been excellent tools to effectively control nocturnal moths [23]. Fullard and Napoleone [21] found that only butterflies (Lepidoptera) were an exclusively diurnal while, moths were active both during day and night time. This is probably also linked to the capability of moths to hear ultrasounds, while butterflies lack the ear structures needed for these abilities [23]. A variety of factors such as light, intensity, wavelength, time of exposure, the direction of light sources, and color of the ambient light influence insect responses [23]. Moreover, depending upon the light source and material the impact of light on insects varies both qualitatively as well as quantitatively [22]. Light sources that emit relatively large amounts of UV radiation (blue fluorescent light, black lights, and mercury lights) strongly attract insects [21]. Apis and other Anthophila from the family can respond to a large wavelength of light that varies from 300-600 nm [4]. Insects with compound eyes like Musca domestica can respond to light from $250-350 \mathrm{~nm}$ [7]. Plodia interpunctella is attracted towards the violet spectrum of light as well as UV light $(380-500 \mathrm{~nm})$ [26]. The reproduction process of Spodoptera litura, Ephestia glycinivora, and Tinea castella moth species is affected by the presence of red, yellow and orange spectrum of light (570-630 nm) [27]. Agrotis ipsilon a type of cutworm moth is highly sensitive to the blue and indigo spectrum of light $(450-490 \mathrm{~nm})$ and usually gets attracted to it [14]. Trialeurodes vaporariorum is negatively phototactic to $400 \mathrm{~nm}$ light but positively phototactic to $550 \mathrm{~nm}$ [27]. The phototactic behaviors of insects are presented in Table 1 along with the wavelength at which insects that are attracted towards the light. 
Table 1. Insects' phototactic behaviors along with the wavelength of light that is attracted towards the light source.

\begin{tabular}{cccccc}
\hline S1. No & Insect Species & Order & $\begin{array}{c}\text { Phototaxis Behavior } \\
\text { Positive (+) or Negative (-) }\end{array}$ & Wavelength (nm) & References \\
\hline 1 & Lasioderma serricorne & Coleoptera & + & $365-550$ & {$[24]$} \\
\hline 2 & Trogoderma granarium & Coleoptera & + & $520-540$ & {$[24]$} \\
\hline 3 & Coccinella septempunctata & Coleoptera & + & 360 & {$[28]$} \\
\hline 4 & Oriu insidious & Hemiptera & + & $310-520$ & {$[21]$} \\
\hline 5 & Trialeurodes & Hemiptera & + & $340-520$ & {$[29]$} \\
\hline 6 & Sitotroga cereallela & Lepidoptera & + & $475-550$ & {$[24]$} \\
\hline 7 & Plodia interpuctella & Lepidoptera & + & $340-365$ & {$[24]$} \\
\hline 9 & Thrips palmi & Thysanoptera & + & $355-735$ & {$[30]$} \\
\hline
\end{tabular}

\subsection{Insect Pest Control to Control Degradation of Heritage Structures}

In current situations, no buffer zone has been demarcated around Ajanta [6]. A $5 \mathrm{~km}$ radius surrounding Ajanta caves should be designated as a green belt as suggested by ASI administered by the Ministry of Forestry and Climate Change, (MoEF and CC) Govt. of India and ASI. Presently, fumigation for insect eradication and polyvinyl alcohol treatment on cave wall paintings is carried out [5]. Grid doors and windows are placed to control the entry of birds and bats inside caves (whc.unesco.org). Although it is conceivable to dispose of silverfish by creating warm and dry conditions that deter their presence, such an environment is difficult to create in the caves, and much more so in caves close to a flowing river inside a natural forest [22]. The addition of a fine wire mesh on the windows of the cave walls has helped in controlling flying insects from entering the cave [31]. Occasionally, some crawling insects are noticed inside the cave, but due to regular disinfection and dusting the site is likely to free from damage due to microorganisms, small insects, and larvae [25]. M. S. Mathur (1968) succeeded in killing the insects with the use of gamma radiation but the method was not used later because of the inability to remove the effects of radiation from the cave surface. Gamma rays are also considered dangerous for the operators using them for small experiments [4]. M. Singh [17] reported chemical solutions for cleaning the painted surface but reducing the chemical used in the caves and heritage structures, in the long run, will be a better remedy. ASI is presently carrying out following precautionary treatments for the preservation and maintenance of Ajanta cave monuments from insects and pests and other biological stresses [4]:

(a) A regular spray of chemicals that includes insecticides and herbicides;

(b) Consolidation of weak and loose plaster on cave walls;

(c) Chemical treatment for the removal of superficial accretions;

(d) Removing old preservative coat followed by applications of new preservative coat;

(e) Regular cleaning of the caves;

(f) Use of bio-pesticides (information not available).

\section{Light-Based Control of Insect Pests}

Archaeological sites are essential parts of the cultural heritage of India and the world especially caves like Ajanta [20]. We must also not try to ignore the fact that caves are home to a variety of unique biodiversity that includes beneficial and harmful insects and many of them are important pollinators like butterfly larvae, moths, bats, and birds [32]. Insect species present around Ajanta should be managed wisely and sustainably for the benefit of both cave monuments and biodiversity in the surrounding areas [24]. Insects damaging cave monuments should be eradicated from archaeological sites with due consideration to not harming beneficial pollinators present in the area [14]. There is increasing evidence that many insects are of considerable economic value because they increase agricultural yields being important pollinators [8]. Until now, no significant research work has been 
carried out for either inventory of insects to understand the current baseline so that effective and efficient insect control strategy can be planned for the preservation of the Ajanta cave. Whatever information regarding insect pests in Ajanta caves is therefore fragmentary, incomplete, and scattered. Light does not cause any harm to the caves and the surrounding environment [7]. Ultraviolet (UV) radiation is visible to insects, and so far nocturnal insects are reported to be attracted to light sources that emit large amounts of UV radiation for forecasting pest outbreaks, electric insect killers, etc. [23]. Acoustic and light behavior of insects can be the strength to address for preserving and protecting cave monuments instead of relying on harmful pesticides and chemicals that are persistent and have a huge impact on the entire ecosystem [31]. The specific wavelength of light can be used as an effective conservation technique for the conservation of caves against insects [33]. The light source can be used to attract the insects and trap them by releasing them far from the location without killing other beneficial pollinator and insects [6]. The trapped insects can be used for the further biodiversity study of insect's species found at that place. So far the Zoological Survey of India (ZSI) or any other organization has not carried out any detailed insect inventory from the caves. The authors are already in the process of developing insect baseline of the cave monument of Ajanta and will be shared in a series of our publications that will be the outcome of the activity in which the authors are involved.

\section{Conclusions and Way Forward}

Archeological sites have always been considered important as cultural heritages for the country and entire humanity. These heritage structures and monuments have undergone immense changes due to an array of factors spread over several decades recently. Ajanta cave is also on the edge of deterioration mainly due to many physical and well as biological stressors and insects are one of them. Due care and attention with well-thought solutions are required to implemented to preserve cave paintings of Ajanta facing massive pressure. Changing and irregular weather conditions coupled with increasing anthropogenic interferences have significantly affected and increased the threats to the heritage monuments. Use of a variety of chemicals to control insect pests has also resulted in increased resistance of insects with stronger and severe impact and damage to these structures. The overview provided in the paper with special reference to factors that have helped in the proliferation of the insect pest population in Ajanta caves and caused damage to paintings and structure will help understand overall concern and drivers to the problem. So far, for the prevention and control of these insect pests, a regular spray of insecticides is carried out by ASI. Though, in the long run, the heavy coating of chemicals may be persistent and may also affect the insect and pollinator diversity of the area. The color of paintings is organic in nature that has been intact for thousands of years but in the last less-than-four decades insects and chemicals have both affected and damaged the paintings. There is a need to understand and see the insect pest problem of Ajanta caves with a broader perspective and scientific lens with a special focus on sustainable and environmentally friendly solutions. The effort of this paper is to highlight this important aspect of the study and to also provide environment-friendly and efficient approaches and solutions that can address the issue without affecting pollinator diversity of the area. Light-based preservation and protection of heritage structure can be used as a cost-effective and efficient approach. Artificial light sources can be both beneficial and harmful to species. Artificial light can disrupt the stability of species and also it is an important factor in the decline of some vulnerable species. Hence, light with an appropriate wavelength can be used as an effective tool for the conservation of monuments from insects by preserving pollinators in the vicinity. More research is being initiated in this direction, especially to understand the important insect pests feeding, breeding, and using the heritage sites as important habitats, a food chain that is present and supporting these insects, so that better understanding can help in designing better solutions. The authors would like to highlight the importance of light-based samplers and techniques through this study though in a very nascent stage and more effective to control agricultural pests and insects can be a very effective control for heritage structures too. Important modifications are to be carried out in the prototype that supports 
"trap and release" mechanism instead of "trap and kill" that helps pollinator diversity of the region and only target insect pests that are affecting the cave paintings and carvings.

Author Contributions: Conceptualization-S.D.; Methodology-S.D. and P.K.; Validation-S.D.; Formal Analysis-S.S. and S.C.; Investigation-S.D., S.S. and S.C.; Resources-S.N.; Data Curation-S.S.; Writing-Original Draft Preparation-S.S.; Writing—Review \& Editing-S.D.; Visualization-S.D. and S.S.; Supervision-S.D. and P.K.; Project Administration-P.K.; Funding Acquisition-S.D. and P.K.

Funding: This research received no external funding.

Acknowledgments: Authors are thankful to Anchal Mittal, CSIR-CBRI, Roorkee and K.V. George, CSIR-NEERI for their support and inputs. Authors also acknowledge CSIR Mission Mode Project No. HCP-0018/5.2.2. Field Staff of ASI, Govt. of India at Ajanta and Forest guards, State Forest Department at Ajanta are also acknowledged for their help in insect sampling near Ajanta caves. Authors also thank Paras R. Pujari, Principal Scientist and Ramesh Janipella, Project Assistant, CSIR NEERI, Nagpur for sharing the information and map of the study area. KRC, CSIR-NEERI Nagpur is acknowledged for plagiarism check of the manuscript under the No. CSIR-NEERI/KRC/2019/APRIL/WTMD-AID-ERMD/1.

Conflicts of Interest: Authors declare no conflict of interest.

\section{References}

1. Bakri, A.F.; Yusuf, N.A.; Jaini, N. Managing Heritage Assets: Issues, Challenges and the Future of Historic Bukit Jugra, Selangor. Procedia Soc. Behav. Sci. 2012, 68, 341-352. [CrossRef]

2. Agrawal, O.P.; Dhawan, S.; Garg, K.L.; Shaheen, F.; Pathak, N.; Misra, A. Study of biodeterioration of the Ajanta wall paintings. Int. Biodeterior. 1988, 121-129. [CrossRef]

3. Agrawal, O.P. Conservation problems of Ajanta wall paintings. Stud. Conserv. 2013, 31, 86-89. [CrossRef]

4. Bharti, G. Ajanta caves: Deterioration and Conservation Problems (A Case Study). Int. J. Sci. Res. Publ. 2013, 3, 1-3. Available online: www.ijsrp.org (accessed on 11 November 2013).

5. Umadi, R.; Dookie, S.; Rydell, J. The Monumental Mistake of Evicting Bats from Archaeological Sites-A Reflection from New Delhi. Heritage 2019, 2, 553-567. [CrossRef]

6. Singh, M.; Arbad, B.R. Conservation and Restoration Research on 2nd BCE Murals of Ajanta. Int. J. Sci. Eng. Res. 2012, 3, 1-8.

7. Brimblecombe, P.; Lankester, P. Long-term changes in climate and insect damage in historic houses. Stud. Conserv. 2013, 58, 13-22. [CrossRef]

8. Barton, H.A. Introduction to cave microbiology: A review for the non-specialist. J. Cave Karst Stud. 2006, 68, 43-54.

9. Deutsch, C.A.; Tewksbury, J.J.; Tigchelaar, M. Increase in crop losses to insect pests in a warming climate. Science 2018, 361, 916-919. [CrossRef]

10. Gontareva, E.F.; Ansari, M.K.; Ruban, D.A.; Ahmad, M.; Singh, T.N. Geological dimension of the cultural heritage: A case example of the Ajanta caves (Maharashtra, India). Cuad. Lab. Xeol. Laxe 2015, 38, 67-78.

11. Uno, T.; Shimazdu, Y. Thermal environment in Ajanta caves. In Proceedings of the Archi-Cultural Translations through the Silk Road, 2nd International Conference, Nishinomiya, Japan, 14-16 July 2012; pp. 191-196.

12. Bankar, M.V.; Bhosle, N.P. Ethnobotanical Survey of Medicinal Plants in Ajanta Region (MS) India. J. Pharm. Biol. Sci. 2017, 12, 59-64. [CrossRef]

13. Singh, M.; Arbad, B.R. Characterization of 4th-5th century A.D. earthen plaster support layers of Ajanta mural paintings. Constr. Build. Mater. 2015, 82, 142-154. [CrossRef]

14. Hueck-Van der Plas, E.H. The microbiological deterioration of porous building materials. Int. Biodeterior. Bull. 1968, 4, 11-28.

15. Lal, B.B. The Murals- their composition and technique. In The Murals: The Preservation of the Ajanta Murals; Ghosh, A., Ed.; Director-General of Archaeological Survey of India: New Delhi, India, 1966.

16. Moiseff, A.; Pollack, G.S.; Hoy, R.R. Steering responses of flying crickets to sound and ultrasound: Mate attraction and predator avoidance. Proc. Natl. Acad. Sci. USA 1978, 75, 4052-4056. [CrossRef] [PubMed]

17. Sterflinger, K.; Piñar, G. Microbial deterioration of cultural heritage and works of art-Tilting at windmills. Appl. Microbiol. Biotechnol. 2013, 97, 9637-9646. [CrossRef]

18. Singh, M.; Arbad, B.R. Architectural History and Painting Art at Ajanta: Some Salient Features. Arts 2013, 2, 134-150. [CrossRef] 
19. Singh, M.; Arbad, B.R. On Carrying capacity of Cave Murals of Ajanta Introduction. Int. J. Sci. Eng. Res. 2013, 4, 4-7.

20. Perry, R.W. A review of factors affecting cave climates for hibernating bats in temperate North America. Environ. Rev. 2013, 21, 28-39. [CrossRef]

21. Wang, S.; Tan, X.L.; Michaud, J.P.; Zhang, F.; Guo, X. Light intensity and wavelength influence development, reproduction and locomotor activity in the predatory flower bug Oriussauteri (Poppius) (Hemiptera: Anthocoridae). J. Biocontrol 2013, 58, 667-674. [CrossRef]

22. Rieswijk, C. Measures to Reduce the Negative Effects of Light Pollution. Master's Thesis, University of Utrecht, Utrecht, The Netherlands, 31 January 2014.

23. Shimoda, M.; Honda, K.I. Insect reactions to light and its applications to pest management. Appl. Entomol. Zool. 2013, 48, 413-421. [CrossRef]

24. Stermer, R.A. Spectral Response of Certain Stored Product Insects to Electromagnetic Radiation. J. Econ. Entomol. 1959, 52, 888-892. [CrossRef]

25. Sheppard, A.D.; Rund, S.S.C.; George, G.F.; Clark, E.; Acri, D.J.; Duffield, G.E. Light manipulation of mosquito behavior: Acute and sustained photic suppression of biting activity in the Anopheles gambiae malaria mosquito. Parasites Vectors 2017, 10, 1-14. [CrossRef] [PubMed]

26. Lum, P.T.M.; Flaherty, B.R. Regulating Oviposition by Plodiainterpunctella in the laboratory by light and dark conditions. J. Econ. Entomol. 1970, 63, 236-239. [CrossRef]

27. Fullard, J.H.; Napoleone, N. Diel flight periodicity and the evolution of auditory defenses in the macrolepidoptera. Anim. Behav. 2001, 62, 349-368. [CrossRef]

28. Lin, J.T. Identification of photoreceptor locations in the compound eye of Coccinella septempunctata Linnaeus (Coleoptera, Coccinellidae). J. Insect Physiol. 1993, 39, 555-562. [CrossRef]

29. Mellor, H.E.; Bellingham, J.; Anderson, M. Spectral efficiency of the glasshouse whitefly Trialeurodes vaporariorum and Encarsia Formosa its hymenopteran parasitoid. Entomol. Exp. et Appl. 1997, 83, 11-20. [CrossRef]

30. Murata, M.; Hariyama, T.; Yamahama, Y.; Toyama, M.; Ohta, I. Effects of the range of light wavelengths on the phototactic behavior and biological traits in the melon thrips, Thrips palmi Karny (Thysanoptera Thripidae). Ethol. Ecol. Evol. 2018, 30, 101-113. [CrossRef]

31. Lal, B.B. Rock paintings of India- A study in conservation. In Conservation of Cultural Property in India; ICCROM: Rome, Italy, 1976.

32. Varotsos, C.; Tzanis, C.; Cracknell, A. The enhanced deterioration of the cultural heritage monuments due to air pollution. Environ. Sci. Pollut. Res. 2009, 16, 590-592. [CrossRef]

33. Ashfaq, M.; Khan, R.A.; Khan, M.A.; Rasheed, F.; Hafeez, S. Insect Orientation to Various Color Lights in the Agricultural Biomes of Faisalabad. Pak. Entomol. 2005, 27, 49-52. 